\title{
Immobilization of cellulase on modified mesoporous silica shows improved thermal stability and reusability
}

\author{
Hailei Yin ${ }^{1 *}$, Zhong-liang Su ${ }^{5}$, Hongbo Shao ${ }^{2,5 *}$, Jinfang Cai ${ }^{1}$, Xiaofei Wang ${ }^{3}$ and Haixia Yin ${ }^{4}$ \\ ${ }^{1}$ Department of Trauma and Orthopaedics, General Hospital of Jinan Military Region, 25, Shi-Fan Rd, Jinan 250031/ \\ No.401 Hospital of People Liberation Army, 22, Min-Jiang Rd, Qingdao 266071, China. \\ ${ }^{2}$ Key Laboratory of Coastal Biology and Bioresources Utilization, Yantai Institute of Coastal Zone Research (YIC), \\ Chinese Academy of Sciences (CAS), Yantai 264003, China. \\ ${ }^{3}$ Out-patient Department of Joint Logistics Department of the Jinan Military Region, 36, Ying Xiong Shan Rd, Jinan \\ 250002, China. \\ ${ }^{4}$ First Retired Cadres of Joint Logistics Department of the Jinan Military Region, 55, Yu-Han Rd, Jinan 250002, China \\ ${ }^{5}$ College of Chemical Engineering/Institute of Life Sciences, Qingdao University of Science and Technology (QUST), \\ Qingdao 266042, China.
}

\begin{abstract}
Cellulase was covalently immobilized using modified mesoporous silica as carrier, and the characters of immobilized cellulase were investigated including the optimum $\mathrm{pH}$, the optimum temperature, thermal stability, reusability, storage stability and enzyme kinetics. As compared to the free enzyme, the optimum $\mathrm{pH}$ of the immobilized cellulase showed no changes, the optimum temperature showed a slight increase to $60^{\circ} \mathrm{C}$. The immobilized enzymes demonstrated enhanced thermal stability, while the free enzymes lost almost $40 \%$ initial activity, the immobilized forms lost only $9 \%$ initial activity within a period of $120 \mathrm{~min}$ at $60^{\circ} \mathrm{C}$. The immobilized cellulase showed excellent reusability. After 11 cycles, the cellulase immobilized on modified mesoporous silica still retained $89 \%$ of its initial activity. At optimized conditions, $\mathrm{Km}$ and Vmax values for the immobilized enzyme were slightly increased when compared with those of free enzyme. The characters of cellulase immobilized on modified mesoporous silica suggest that the immobilized enzyme has high potential for application in the industrial degradation of cellulose.
\end{abstract}

Key words: Renewable energy, cellulose, immobilization, mesoporous silica, cellulose.

\section{INTRODUCTION}

The growing demand for energy and diminishing fossil fuel reserves have stimulated tremendous interest in finding alternative renewable energy sources (Huang et al., 2011). Over the past few decades, a large number of research efforts have focused on the cellulose, because cellulose is the most abundant renewable biomass in the world, and it can be converted into biofuels, such as ethanol after cellulose is degraded to sugar (Huang et al., 2011). Many methods have been used for the degradation of cellulosic materials to sugars, such as acidolysis
(Li et al., 2010), alkaline hydrolysis (Carrillo et al., 2005) and enzymatic hydrolysis (Park et al., 2002). Among these methods, the enzymatic hydrolysis has received great attention due to the fact that the enzymatic process has the potential to convert the lignocellulosic materials to ethanol with a high yield and low production cost (Wingren et al., 2003; Galbe and Zacchi, 2002; Kannan and Jasra, 2011). However, the cost of ethanol production from lignocellulosic materials is relatively high based on current enzymatic hydrolysis technologies, and the main 
challenges are the low yield and high cost of the hydrolysis process (Sun and Cheng, 2002). The difficulties above can be partly overcome by the immobilization of cellulase due to the fact that celulase can be reused while retaining its specificity and stability (Kannan and Jasra, 2011). The capacity to retain or recover enzymes also allows biocatalyst separation from product, thereby permitting continuous processes, and prevents carrythrough of protein or activity to subsequent process steps (Polizzi et al., 2007; Brady and Jordaan, 2009).

However, an often made observation for immobilization of enzymes is that in comparison to the base preparation, they have reduced specific activity but have acquired extra shelf-lifetime and stability under the operational conditions (Roessl et al., 2010). Many factors can affect the activity of the immobilized enzyme, such as the immobilized procedure, carrier and so on. Different carriers can provide different external backbone for the enzyme molecules, which is expected to improve the stability of enzyme molecules at reaction conditions (Temoçin and Yiğitoğlu, 2009). There are many different materials which have been proposed to immobilize enzymes, including Ca-alginate, agar, K-Carrageenin, polyacrylamide, nylon, cellulose, polysulfone, alumina, silica, porous glass, ceramics, diatomaceous earth, clay and bentonite (Hu et al., 2007). Among these materials, mesoporous silica is the most commonly used supporter for the immobilized enzyme because of its advantages (Hu et al., 2007; Wang et al., 2009). Siso et al. (1990) have reported that after a-amylase was immobilized on porous silica, external diffusional resistances to mass transfer were minimized when the immobilized enzyme was operated in a packed bed reactor.

In this study, the cellulase is immobilized covalently on mesoporous silica, and the optimum temperature, the optimum $\mathrm{pH}$, the reusability, the thermal stability and the storage stability of immobilized cellulase are determined. In addition, the studies have demonstrated that the reusability and thermal stability of immobilized cellulase are significantly improved as compared to the enzyme immobilized onto chitosan. The mesoporou silica may be used as an excellent support for cellulase immobilization.

\section{MATERIALS AND METHODS}

\section{Chemicals}

The cellulase (dissolved in $0.1 \mathrm{~mol} / \mathrm{L}$ citric acid - sodium hydrogen phosphate buffer, $\mathrm{pH}=4,1.42 \mathrm{mg} / \mathrm{ml}$ ) was kindly provided by Kangdien CO, LTD. Mesoporou material SBA-7 was prepared by our laboratory. All other chemicals were of purest grade available commercially.

\section{Immobilization of cellulase}

SBA-7 was amino functionalized using the method as described by Gao et al. (2006). The modified SBA-7 was labeled SBA-7-A. The SBA-7-A $(0.25 \mathrm{~g})$ was added into $5 \mathrm{ml}$ of solution containing 0.015 $\mathrm{mg} / \mathrm{mL}$ of glutaraldehyde and vigorously stirred for $1 \mathrm{~h}$ at room tem- perature. It was centrifuged, washed several times with water till all excess of glutaraldehyde was removed. The glutarated SBA-7-A was mixed with $2.5 \mathrm{~mL}$ cellulase solution and shaken for $4 \mathrm{~h}$ at room temperature. After centrifuging and washed with deionized water, the immobilized cellulase was obtained.

\section{Activity measurement}

The activity of immobilized cellulase was estimated according to the method described by Su et al. (2012).

\section{Optimum temperature}

The optimum temperature of immobilized cellulase was tested at $\mathrm{pH}$ 4.0 using $1 \%(\mathrm{w} / \mathrm{v}) \mathrm{CMC}$ (dissolved in $0.1 \mathrm{~mol} / \mathrm{L}$ citric acid - sodium hydrogen phosphate buffer) as substrate. After $20 \mathrm{~min}$, glucose product in solution was measured at $40,50,60,70$ and $80^{\circ} \mathrm{C}$. The activity of the immobilized enzyme was determined using the method as described by Shoemaker and Brown (1978).

\section{Optimum pH}

The immobilized cellulase was pre-equilibrated by washing with 0.1 $\mathrm{mol} / \mathrm{L}$ citric acid- sodium hydrogen phosphate buffer of correspondding test $\mathrm{pH}$ for several times. Substrate solutions of $1 \%(\mathrm{w} / \mathrm{v}) \mathrm{CMC}$ in $0.1 \mathrm{~mol} / \mathrm{L}$ citric acid- sodium hydrogen phosphate buffer at $\mathrm{pH}$ values ranging from 3.0 to 7.0 were prepared. The immobilized cellulases were added into corresponding CMC solutions, and glucose productions were determined after $20 \mathrm{~min}$ at $60^{\circ} \mathrm{C}$.

\section{Thermal stability}

The immobilized cellulase was incubated at $\mathrm{pH} 4.0$ and $60^{\circ} \mathrm{C}$, and $100 \mathrm{mg}$ immobilized enzyme was taken out at 20 min intervals. The activity was determined using the method described above.

\section{Reusability}

One hundred milligram immobilized cellulase was put into $3 \mathrm{~mL}$ of $1 \%(\mathrm{w} / \mathrm{v}) \mathrm{CMC}$ solution (dissolved in $0.1 \mathrm{~mol} / \mathrm{L}$ citric acid- sodium hydrogen phosphate buffer, $\mathrm{pH}=4.0$ ) and incubated at $60^{\circ} \mathrm{C}$ for 25 min all together in a water bath. At the end of the reaction, the immobilized cellulase was removed from the solution, washed with $0.1 \mathrm{~mol} / \mathrm{L}$ citric acid- sodium hydrogen phosphate buffer and put again into other $3 \mathrm{~mL}$ of $1 \%(\mathrm{w} / \mathrm{v})$ of $\mathrm{CMC}$ solution to start a new reaction.

\section{Storage stability}

The immobilized cellulase was stored at $4^{\circ} \mathrm{C}$ in $0.1 \mathrm{~mol} / \mathrm{L}$ citric acidsodium hydrogen phosphate buffer $(\mathrm{pH}=4.0)$. The activity was tested at different time using the method as described above.

\section{Enzyme kinetics of immobilized cellulase}

These values were determined at the optimum condition, and carboxymethylcellulose with different concentrations (1\%, 1/300, 1/500 and $1 / 700(\mathrm{w} / \mathrm{v})$, dissolved in $0.1 \mathrm{~mol} / \mathrm{L}$ citric acid- sodium hydrogen phosphate buffer, $\mathrm{pH}=4.0$ ) was used as a substrate. $100 \mathrm{mg}$ immobilized cellulase was added into $9 \mathrm{~mL}$ sodium carboxymethylcellulose solutions above, and glucose production in different concentration carboxymethylcellulose solutions after 4, 8, 12, 16 


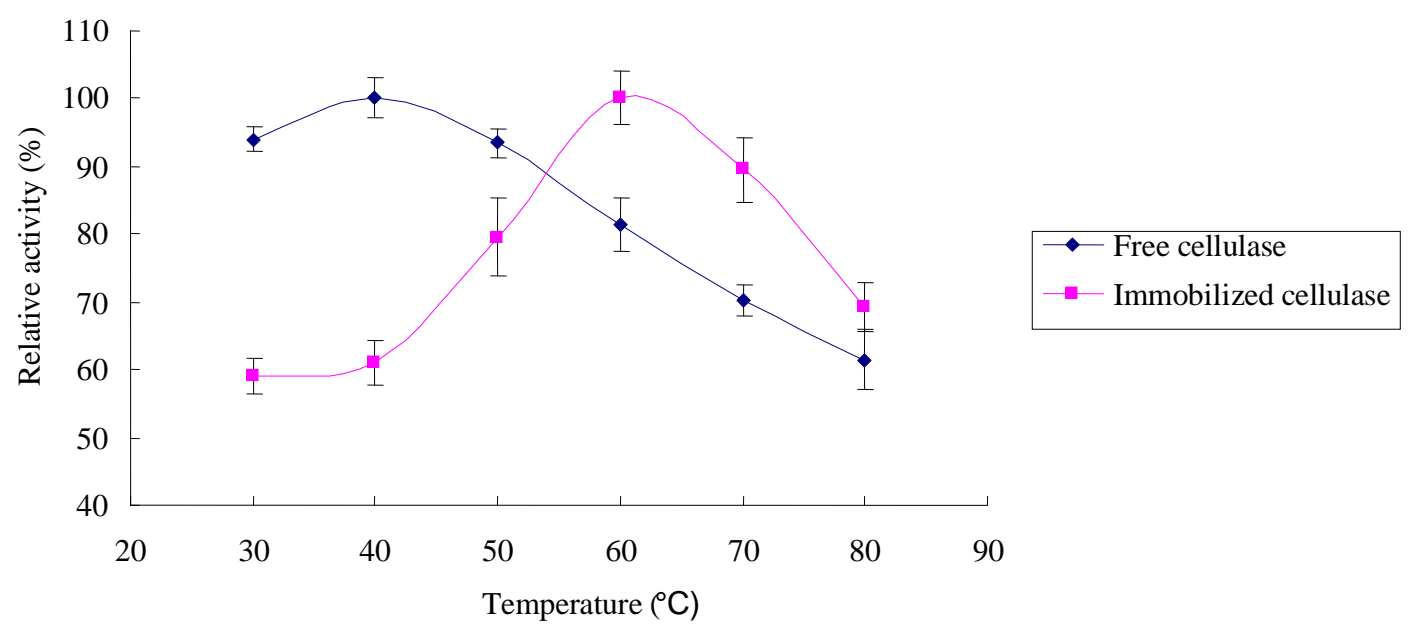

Figure 1. Effect of temperature on immobilized cellulose at $\mathrm{pH} 4.0$ using $1 \%(\mathrm{w} / \mathrm{v}) \mathrm{CMC}$ as the substrate. Data are means \pm RSE (relative standard error), $n=3$, with $1 \%(w / v) C M C$ as the substrate.

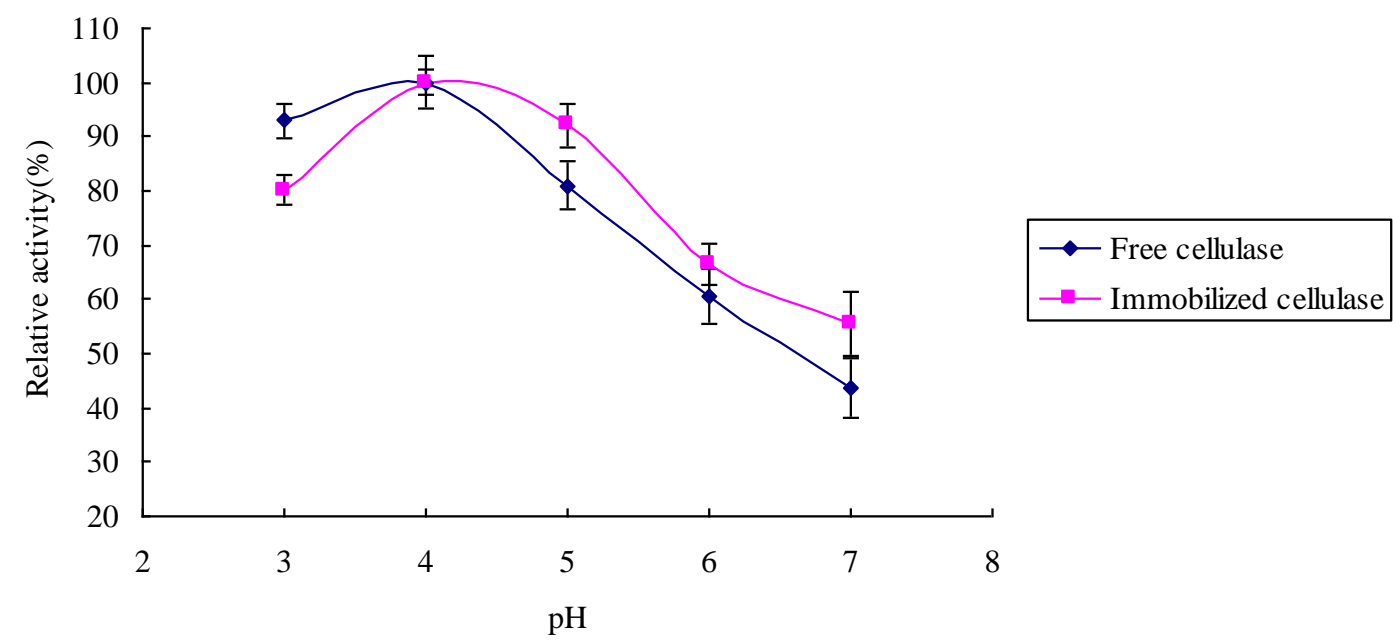

Figure 2. Effect of $\mathrm{pH}$ on immobilized cellulose at $60^{\circ} \mathrm{C}$ using $1 \%(\mathrm{w} / \mathrm{v}) \mathrm{CMC}$ as the substrate. Data are means \pm RSE (relative standard error), $n=3$.

and 20 min at $60^{\circ} \mathrm{C}$ was determined. $\mathrm{Km}$ and Vmax values were calculated from Lineweaver-Burke plots.

\section{RESULT AND DISCUSSION}

\section{Effect of temperature and $\mathrm{pH}$ on immobilized cellulase}

The optimum temperature for cellulose hydrolysis is shown in Figure 1 for free and immobilized cellulases. The immobilized cellulases exhibited maximal activity at $60^{\circ} \mathrm{C}$, higher than that of free cellulase $\left(40^{\circ} \mathrm{C}\right)$, which indicated that the support material retained the tertiary structure of the enzyme at higher temperature. Other authors have also obtained similar observations (Andriani et al., 2012). The effect of $\mathrm{pH}$ on the activity of immobilized and free cellulases are given in Figure 2. The maximum activity for the immobilized and free cellulases was observed at $\mathrm{pH}$ 4. However, when compared with the free cellulase, the relative activity of the immobilized cellulase is higher for the $\mathrm{pH}$ value ranging from 4 to 7 . The stability of the immobilized enzymes at higher $\mathrm{pH}$ values can be due to the residual charges on the solid matrix and the nature of the bound enzyme (Jaiswal and Prakash, 2011). Immobilized cellulase stable at higher $\mathrm{pH}$ are more suitable for industrial applications.

\section{Thermal stability}

Thermal stability of immobilized enzyme is a very important character for its industrial applications. The thermal stability of immobilized and free cellulases was investigated at $60^{\circ} \mathrm{C}$ using $\mathrm{CMC}$ as the substrate. The results (Figure 3) showed a significant increase in thermal stabi- 


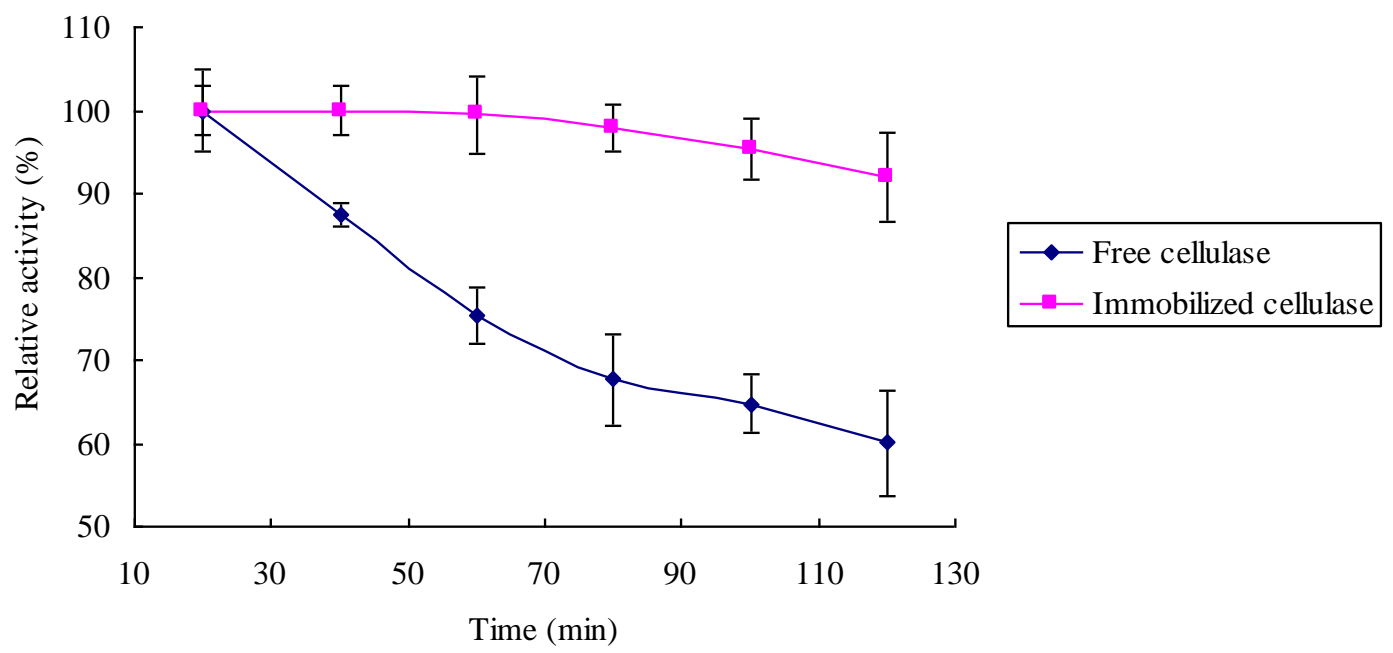

Figure 3. Thermostability of free and immobilized cellulose at $\mathrm{pH} 4.0$ and $60^{\circ} \mathrm{C}$ using $1 \%(\mathrm{w} / \mathrm{v})$ $\mathrm{CMC}$ as the substrate. Data are means \pm RSE (relative standard error), $\mathrm{n}=3$.

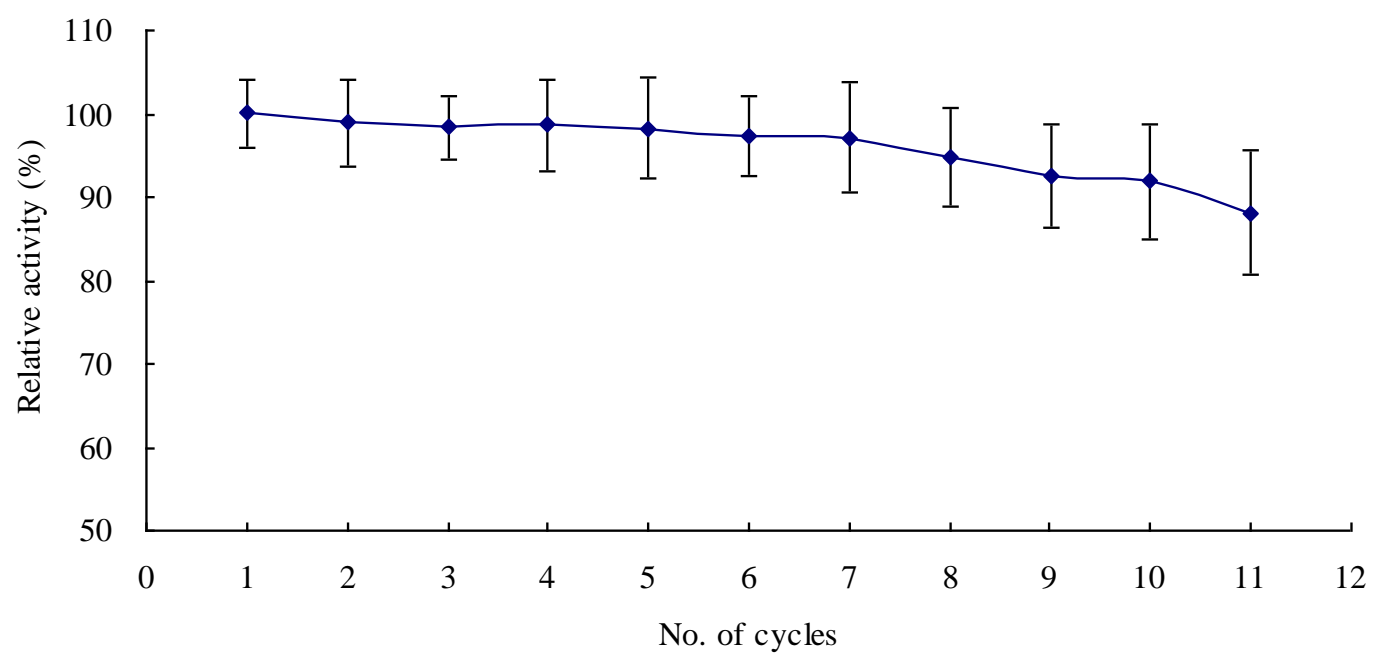

Figure 4. Reusability of immobilized cellulose at $\mathrm{pH} 4.0$ and $60^{\circ} \mathrm{C}$ using $1 \%(\mathrm{w} / \mathrm{v}) \mathrm{CMC}$ as the substrate. Data are means \pm RSE (relative standard error), $n=3$.

lity as compared to the free enzyme. After $120 \mathrm{~min}$, the immobilized cellulase preserved $91.9 \%$ initial activity. At the same time, the free cellulase maintained $60.1 \%$ initial activity for $120 \mathrm{~min}$. Immobilized cellulase displayed excellent thermal stability. The increase in thermal stability of the immobilized enzyme could be attributed to multipoint attachment of the enzyme to the carrier preventing them against the autolysis (Esawy and Combet-Blanc, 2006). Ruchi and Kharel (2005) have also obtained similar observations.

\section{Reusability}

The activity of immobilized cellulase was evaluated using a repeated batch process in order to observe the reuse of the immobilized enzyme (Figure 4). The results showed that the immobilized cellulase could be used for 7 consecutive cycles without obvious loss of activity. After 11 cycles, it still retained $88 \%$ of its initial activity. The immobilized enzyme may have been protected from thermal denaturation by the modified mesoporous silica. As compared to our previous results where the cellulase was immobilized on chitosan (Su et al., 2012), the immobilization of cellulase on modified mesoporous silica has improved reusability of the enzyme. These indicate that the modified mesoporous silica is an excellent material which can be used for cellulase immobilization.

\section{Storage stability}

Storage stability of immobilized and free cellulases was studied in $0.1 \mathrm{~mol} / \mathrm{L}$ citric acid- sodium hydrogen phos- 


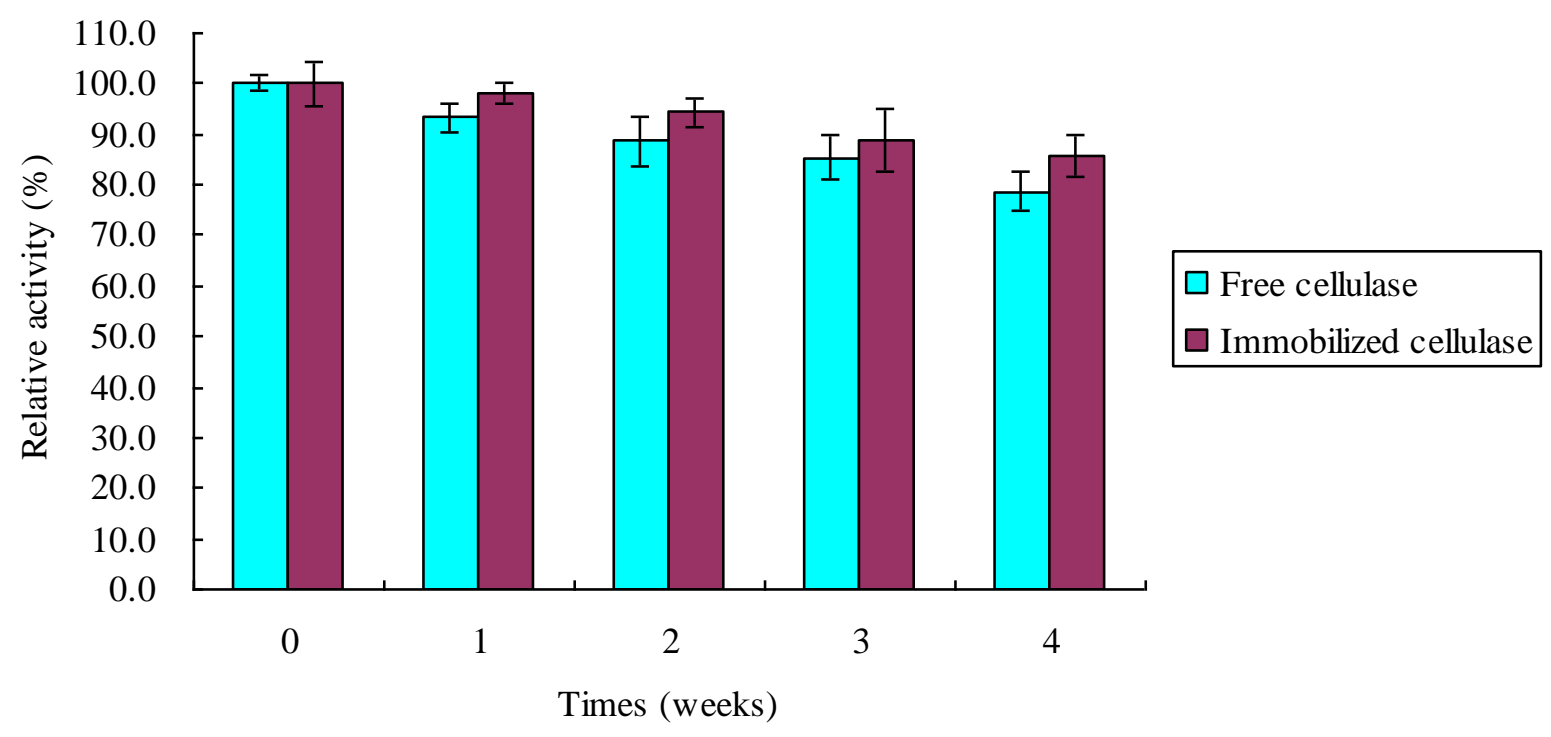

Figure 5. Storage stability of immobilized and free cellulose. Data are means \pm RSE (relative standard error), $n=3$.

phate buffer solution of optimum $\mathrm{pH}$ and the results are shown in Figure 5. It can be seen that the immobilized cellulase showed a gradual decrease in activity and lost $14 \%$ initial activity only after 4 weeks while the free cellulase lost $23 \%$ activity in the same time. The immobilized cellulase showed favorable storage stability. The improved storage stability of immobilized enzymes can be attributed to a reduction in the rate of denaturation of the enzyme as a result of fixation on the carrier (Sanjay and Sugunan, 2008; Bayramoglu et al., 2003; Cirpan et al., 2003).

\section{Enzyme kinetics of free and immobilized xylanase}

For the two forms of cellulas, linearity of the LineweaverBurk plot showed Michaelis-Menten kinetics. The Km value for the immobilized and free cellulase was 4.03 and $1.84 \mathrm{mg} / \mathrm{L}$, respectively, and the $\mathrm{Vm}$ value for the immobilized and free cellulase was 0.0278 and 0.0036 $\mathrm{mg} / \mathrm{ml} / \mathrm{min}$, respectively. The $\mathrm{Km}$ of immobilized is higher than the free cellulase, suggesting a reduced affinity for the substrate. Tu et al. (2006) had also reported that the $\mathrm{Km}$ of $\beta$-glucosidase on Eupergit $\mathrm{C}$ was 10 times higher than the free $\beta$-glucosidase. The increase in $\mathrm{Km}$ of immobilized enzyme might be due to inaccessibility of the substrate to the enzyme due to limitation in diffusion of substrate into the pores channel of modified mesoporous silica carrier (Andriani et al., 2012). Interestingly, immobilization resulted in about an 8-fold increase in $\mathrm{Vm}$. The increase in the $\mathrm{Vm}$, compared with that of the native enzyme, may be attributed to increased stability of the enzyme after immobilization (Andriani et al., 2012).

\section{Conclusions}

Cellulase was successfully immobilized on modified meso- porous silica carrier using covalent binding. The immobilized cellulase showed higher temperature optima, increased tolerance to higher $\mathrm{pH}$ range, and better thermal stability as compared to free enzyme. The modified mesoporous silica carrier employed in this study allows the immobilized enzyme to be effectively reused at least ten times. In conclusion, as compared to other carriers, modified mesoporous silica is a good supporting material for the immobilization of cellulase.

\section{ACKNOWLEDGEMENTS}

This research was supported by National Natural Science Foundation of China (No. 30900126), One HundredTalent Plan of Chinese Academy of Sciences (CAS) and the CAS/SAFEA International Partnership Program for Creative Research Teams-Typical Environmental Processes.

\section{REFERENCES}

Andriani D, Sunwoo C, Ryu HW, Prasetya B, Park DH (2012). Immobilization of cellulase from newly isolated strain Bacillus subtilis TD6 using calcium alginate as a support material. Bioprocess Biosyst. Eng., 35: 29-33.

Brady D, Jordaan J (2009). Advances in enzyme immobilization. Biotechnol. Lett., 31: 1639-1650.

Bayramoglu G, Akgol S, Bulut A, Denizli A, Arica MY (2003). Covalent immobilization of invertase onto a reactive film composed of 2 hydroxyethyl methacrylate and glycidyl methacrylate: properties and application in a continuous flow system. Biochem. Eng. J. 14: 117126.

Carrillo F, Lis MJ, Colom X, López-Mesas M, Valldeperas J (2005). Effect of alkali pretreatment on cellulase hydrolysis of wheat straw: Kinetic study. Process Biochem., 40(10): 3360-3364.

Cirpan A, Alkan S, Toppare L, Yagci Y, Hepuzer Y (2003). Immobilization of invertase in conducting copolymers of 3-methylthienyl methacrylate. Bioelectrochemistry, 59: 29-33. 
Esawy MA, Combet-Blanc $Y$ (2006). Immobilization of Bacillus licheniformis $5 \mathrm{~A} 1$ milk-clotting enzyme and characterization of its enzyme properties. World J. Microb. Biot., 22: 197-200.

Gao B, Zhu GS, Fu XQ, Teng LR, Chen J, Wang CY, Qiu SL, (2006). Modification of $\mathrm{M}$ esoporous $\mathrm{M}$ aterial and Stability of Immobilization of Penicillin G Acylase. Chem. J. Chinese U., 27(10): 1823-1826.

Galbe M, Zacchi G (2002). A review of the production of ethanol from softwood. Appl. Microbiol. Biotechnol., 59: 618-628.

Huang R, Su R, Qi W, He Z (2011). Bioconversion of Lignocellulose into Bioethanol: Process Intensification and Mechanism Research. Bioenerg. Res. 4: 225-245.

Hu X, Zhao X, Hwang HM (2007). Comparative study of immobilized Trametes versicolor laccase on nanoparticles and kaolinite. Chemosphere, 66: 1618-1626.

Jaiswal N, Prakash O, (2011). Immobilization of Soybean $\alpha$-amylase on Gelatin and its Application as a Detergent Additive. Asian J. Biochem., 6(4): 337-346.

Kannan K, Jasra RV (2011). Improved catalytic hydrolysis of carboxy methyl cellulose using cellulase immobilized on functionalized meso cellular foam. J. Porous Mater., 18(4): 409-416.

Li B, Filpponen I, Argyropoulos DS (2010). Acidolysis of Wood in Ionic Liquids. Ind. Eng. Chem. Res., 49: 3126-3136.

Park EY, Ikeda Y, Okuda N (2002). Empirical evaluation of cellulase on enzymatic hydrolysis of waste office paper. Biotechnol. and Bioprocess Eng., 7(5): 268-274.

Polizzi KM, Bommarius AS, Broering JM, Chaparro-Riggers JF (2007). Stability of biocatalysts. Curr. Opin. Chem. Biol., 11: 220-225.

Roessl U, Nahalka J, Nidetzky B (2010). Carrier-free immobilized enzymes for biocatalysis. Biotechnol. Lett., 32: 341-350.

Ruchi GL, Khare SK (2005). Immobilization of xylan-degrading enzymes from Scytalidium thermophilum on Eudragit L-100, World J. Microb. Biot., 21: 1123-1128.

Sun Y, Cheng J (2002). Hydrolysis of lignocellulosic materials for ethanol production: a review. Bioresource Technol., 83(1): 1-11.
Sanjay G, Sugunan S, (2008). Acid activated montmorillonite: an efficient immobilization support for improving reusability, storage stability and operational stability of enzymes. J. Porous Mater., 15: 359-367.

Su ZL, Yang XY, Li L, Shao HB, Yu ST (2012). Cellulase immobilization properties and their catalytic effect on cellulose hydrolysis in ionic liquid. Afr. J. of Microbiol. Res., 6(1): 64-70.

Shoemaker SP, Brown RD, (1978). Characterization of endo-1, 4-beta$D$ - glucanases purified from Trichoderm a virid. Biochim. Biophys. Acta., 523: 147-161.

Siso MIG, Graber M, Condoret JS, Combes D (1990). Effect of diffusional resistances on the action pattern of immobilized alphaamylase, J. Chem. Technol. Biotechnol., 48: 185-200.

Temoçin Z, Yiğitoğlu M (2009). Studies on the activity and stability of immobilized horseradish peroxidase on poly(ethylene terephthalate) grafted acrylamide fiber. Bioprocess Biosyst. Eng., 32: 467-474.

Tu MB, Zhang X, Kurabi A, Gilkes N, Mabee W, Saddler J (2006). Immobilization of $\beta$-glucosidase on Eupergit $C$ for lignocellulose hydrolysis. Biotechnol. Lett., 28: 151-156.

Wang P, Hu Xi, Cook S, Hwang HM (2009). Influence of Silica-Derived Nano-Supporters on Cellobiase After Immobilization. Appl., Biochem., Biotechnol.,158: 88-96.

Wingren A, Galbe M, Zacchi G (2003). Techno-economic evaluation of producing ethanol from softwood: comparison of SSF and SHF and identification of bottlenecks. Biotechnol. Prog., 19(4): 1109-17. 